\title{
JUURNAL.RU
}

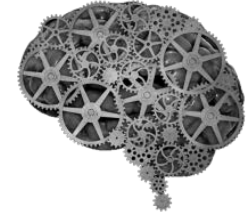

COMPANY GROUP "INTELLEKT"

Гуляева Н.Н. Городская больница № 1 им. Н.А. Семашко Ростов-на-Дону, Россия

doi: 10.18411/lj2016-3-14

\section{Влияние бетасерка на слуховую функцию при болезни Меньера}

Известно, что болезнь Меньера характеризуется периодически возникающими приступами системного головокружения, наличием шума в ухе и прогрессирующим снижением слуха [1]. Степень выраженности слуховых и вестибулярных нарушений с годами приобретает различную направленность: если вестибулярные нарушения постепенно ослабевают, то слуховые расстройства часто заканчиваются развитием стойкой тугоухости и даже глухоты [2]. В связи с этим стабилизация слуховой функции как один из моментов социальной реабилитации больного должна быть предметом особого внимания врача.

В комплексе средств медикаментозного лечения кохлеовестибулярных нарушений важное место отводится вазоактивным препаратам. Эти препараты должны отвечать ряду требований, главное из которых - воздействие на церебральную гемодинамику, что обеспечивает улучшение кровообращения области вестибулярных ядер. Однако для лечения болезни Меньера необходимо улучшение кровоснабжения как ядерного, так и периферического отделов слухового и вестибулярного анализаторов.

К сожалению, далеко не все вазоактивные препараты центрального действия способны оптимизировать кровообращение внутреннего уха. Одним из немногих средств, которым присуще это свойство, является бетагистина 
дигидрохлорид. Фармакологические исследования на животных выявили увеличение кохлеарного кровотока при введении бетагистина дигидрохлорида. Этот эффект зависит от дозы препарата и в большей степени проявляется в сосудистой сети улитки, чем в системном сосудистом русле.

Вазоактивный эффект бетагистина дигидрохлорида отмечен не только во внутреннем ухе, но и в сосудах головного мозга. Скорее всего, он опосредован пресинаптическими адренергическими рецепторами, для которых гистамин играет роль модулятора.

Целью нашего исследования было изучение влияния бетасерка (бетагистина дигидрохлорида) на слуховую функцию у больных с болезнью Меньера.

Бетасерк был использован для курсового лечения 14 больных в возрасте от 28 до 44 лет, 11 женщин и 3 мужчин. Продолжительность заболевания составляла в среднем 2,7 года. Все больные жаловались на одностороннюю флюктуирующую тугоухость и шум в ухе, усиливающийся накануне и во время приступа головокружения. Типичные приступы системного головокружения наблюдались от 2 до 8 раз в год.

Больным проведено общеклиническое и отоневрологическое исследование, произведена тональная пороговая аудиометрия и компьютерная реоэнцефалография (РЭГ).

По данным аудиометрии у всех больных отмечено повышение порогов слуха по воздушной проводимости в зоне речевых частот от 20 до 50 дБ. Преобладающим типом кривых был вогнутый, с наличием костно-воздушного интервала от 10 до 30 дБ на низких частотах.

На РЭГ у всех больных выявлена церебральная ангиодистония по гипертоническому типу с преобладанием ангиоспазма в вертебробазилярном бассейне.

Больным проведено лечение бетасерком в дозах, рекомендуемых фирмой производителем: по 24 мг 2 раза в день. Продолжительность лечения составила 3 
месяца. Результаты лечения оценивали по окончанию приема препарата и по истечению срока от 8 до16 месяцев.

Субъективное улучшение отмечено не ранее чем через 3 недели от начала приема препарата. Стабилизация вестибулярной функции достигнута у всех больных - повторения приступов головокружения в указанные сроки наблюдения не отмечено.

Аудиогические нарушения регрессировали у 9 больных, при аудиометрическом исследовании которых выявлено понижение порогов слуха по воздушной проводимости на 15 - 30 дБ по сравнению с исходными значениями, по костной - на 10 - 20 дБ. 3 больных отметили ослабление или исчезновения субъективного ушного шума.

При исследовании мозгового кровообращения отмечено увеличение кровенаполнения в сосудах вертебробазилярного бассейна.

Таким образом, у большинства больных, принимавших бетасерк, зарегистрировано улучшение слуховой функции. Важным прогностическим моментом является развитие у этих больных стойкой вестибулярной компенсации, поскольку на состояние слухового рельефа оказывает влияние частота и выраженность приступов головокружения: с нарастанием их частоты и продолжительности нарушения слуха прогрессируют.

Наши наблюдения свидетельствуют о высокой эффективности бетасерка в лечении болезни Меньера, что согласуется с данными других авторов [3, 4]. В результате курсового применения препарата не только достигнута вестибулярная ремиссия, но и отмечено стойкое улучшение слуховой функции у $64 \%$ больных. Осложнений и побочных явлений при приеме препарата не зарегистрировано. 


\section{Литература:}

1. Бойко Н.В. Головокружение в практике врача-терапевта. Лечащий врач. 2010; 4: 86.

2. Бойко Н.В., Колмакова Т.С. Содержание гормонов в крови при болезни Меньера. Рос. оторинолар. 2014; 72 (5): 15-19.

3. Djelilovic-Vranic J, Alajbegovic A, Tiric-Campara M, Volic A, Sarajlic Z, Osmanagic E, Todorovic L, Beslagic O. Betahistine or Cinnarizine for treatment of Meniere's disease. Med Arh. 2012; 66(6): 396-398.

4. Della Pepa C, Guidetti G, Eandi M. Betahistine in the treatment of vertiginous syndromes: a meta-analysis. Acta Otorhinolaryngol Ital. 2006; 26(4): 208-15. 